\title{
Rescue of caprine fetal ovaries, vitrification and follicular development after xenotransplantation in two immunodeficient mice models
}

\author{
Muriel Magda Lustosa Pimentel ${ }^{1,2}$ (D), Fernanda Araujo dos Santos ${ }^{2}$ (D) , Luã Barbalho de Macêdo ${ }^{2}$ (D), \\ Parmênedes Dias de Brito ${ }^{2}$ (D), Gabriela Liberalino Lima ${ }^{3}$ (D), Raimundo Alves Barreto Junior ${ }^{4}$ (D), \\ Marcelo Barbosa Bezerra ${ }^{4 \star}$ (1) \\ ${ }^{1}$ Centro Universitário Cesmac, Maceió, AL, Brasil \\ 2Programa de Pós-graduação em Ciência Animal, Universidade Federal Rural do Semi-Árido, Mossoró, RN, Brasil \\ ${ }^{3}$ Departamento de Ciência Animal, Instituto Federal de Educação, Ciência e Tecnologia do Ceará, Crato, CE, Brasil \\ ${ }^{4}$ Departamento de Ciência Animal, Universidade Federal Rural do Semi-Árido, Mossoró, RN, Brasil
}

How to cite: Pimentel MML, Santos FA, Macêdo LB, Brito PD, Lima GL, Barreto Junior RA, Bezerra MB. Rescue of caprine fetal ovaries, vitrification and follicular development after xenotransplantation in two immunodeficient mice models. Anim Reprod. 2020;17(2):e20190115. https://doi.org/10.1590/1984-3143AR2019-0115

\begin{abstract}
Domestic and wild goats are very susceptible animals to predation, specially when pregnancy occurs. This study aimed to evaluate the use of goat fetal ovarian tissue for vitrification followed by xenotransplantation and fresh xenotransplantation in two immunosuppressed mice models (C57BL/6 SCID and Balb-C NUDE). Goat fetus ovaries were collected in slaughterhouses, divided into small cortical pieces and were destined for fresh xenotransplantation (FX) and cryopreservation followed by xenotransplantation (CX). Five recipients from each lineage were used for FX and 10 animals from each lineage for CX. The mice were euthanized after 65 postoperative days, and the transplants were collected for microscopic assessment. The blood plasma was collected for estradiol measurement. Independently of mice strain, all recipients presented complete estrus cycle in FX and $80 \%$ after CX groups. Follicles were observed at all development stages without morphological changes. The volume density and total vessel surface observed in the transplants were different $(p<0.01)$ between groups. The estradiol levels in the recipients did not differ $(p<0.05)$ among the treatments. Thus, it is possible to activate the preantral follicles in the ovaries of fetuses by optimizing germplasm utilization and conservation of domestic and endangered wild goats that are in predatory situations, undesirable drowning or accidental death, since provided conditions for xenotransplantation are performed.
\end{abstract}

Keywords: cryopreservation, assisted reproductive technology, livestock.

\section{Introduction}

In recent years, a growing number of studies have been associating goat species with commercially established reproductive biotechniques, aiming to increase the productivity of these animals in breeding programs. Among the mentioned biotechnology, we highlight Artificial Insemination (Pellicer-Rubio et al., 2016), Embryo Transfer (Fonseca et al., 2016) and in vitro Production of Embryos (Hajian et al., 2017). Goats have also been the species of choice in developing techniques such as Cloning (Yang et al., 2016), Transgenesis (Bertolini et al., 2016) and as an association model between both using goat fetuses as donors (Baguisi et al., 1999). The development of preantral follicles have been experimentally studied in vitro (Saraiva et al., 2010; Magalhães et al., 2011; Leal et al., 2018) and in vivo by Autotransplantation (Santos et al., 2009, Donfack et al., 2018). Additionally, these animals can be used as

*Corresponding author: mbezerra@ufersa.edu.br

Received: September 8, 2019. Accepted: June 8, 2020.

Financial support: None.

Conflicts of interest: The authors have no conflict of interest to declare.

(c) (i) Copyright ( $)$ The Author(s). This is an Open Access article distributed under the terms of the Creative Commons Attribution License, which permits unrestricted use, distribution, and reproduction in any medium, provided the original work is properly cited. 
experimental models for humans, furnishing important results in endocrinology and for assessment of ovarian function, corroborating the observations of physiological similarities between humans and goats in these processes (Liu et al., 2008).

In another context, the incidence of small wild ruminants of autochthonous breeds or imported for commercial purposes, that suffer predation is a recurrent fact in the nature and in small livestock farms. Specifically, domestic and wild goats are easy prey for domestic and wild carnivores (Durawo et al., 2017; Roshnath et al., 2017; Khan et al., 2018), and once pregnant, newborn and kids of goats exhibit less mobility and are more easily predated (Durawo et al., 2017), the loss of genetic material in these conditions of vulnerability may prove invaluable.

Based on the context described above, researches have been carried out in the animal reproduction area aiming to increase the reproductive potential of animals with high zootechnical value (Commin et al., 2012) or preservation of endangered mammals (Gastal et al., 2017) such as cervids (Comizzoli and Wildt, 2013; Comizzoli, 2015). Ovary tissue xenotransplantation is a potential technique for maintaining and developing genetic material, especially when combined with germplasm preservation methods such as vitrification, allowing better planning and preparation by the involved research teams. In addition, the combination of ovarian tissue cryopreservation with xenotransplantation in immunodeficient recipients has demonstrated scientific relevance with considerable follicular development (Santos et al., 2010; Aerts et al., 2010; Wiedemann et al., 2012; Praxedes et al., 2018).

Aiming to reduce rejections after xenotransplantation, genetic manipulations were carried out by researchers who produced immunodeficient rodents to be used as recipients, for example the C57BL6 SCID and BALB / c Nude lines, with the possibility of using both female (Senbon et al., 2005) and males receptors (Hernandez-Fonseca et al., 2005) for the performance of ovarian xenotransplantation. This being an indispensable requirement for the development of transplanted tissues. Thus, this study aimed to evaluate the development and viability of fresh xenotransplantation or xenotransplantation after cryopreservation of fetal goat ovarian tissue in two different immunodeficient mice lineages.

\section{Material and methods}

This work was carried out in accordance with the recommendations of the Brazilian Code of Animal Experimentation (COBEA) (1988) and was approved by the Ethics Committee on Animal Use (CEUA) of the institution under protocol number 23091006934/2015-73.

\section{Ovarian donors}

Ovaries from goat fetuses aged 120 to 140 days of gestation were collected immediately after slaughtering pregnant females at the local slaughterhouse. The ovaries were washed with $0.9 \%$ saline solution, inserted in sterile conical tubes $(50 \mathrm{~mL})$, identified according to the slaughter sequence, and then transported in saline with antibiotics $(100 \mu \mathrm{g} / \mathrm{mL}$ of penicillin) and kept at a temperature of $37^{\circ}$ until arriving at the laboratory to be processed.

Six pairs of goat fetus ovaries with gestational age ranging from 120 to 140 days, undefined breed, were collected from the local slaughterhouse. The ovaries were washed with $0.9 \%$ saline solution, then transported in sterile tubes $(50 \mathrm{~mL})$ containing $0.9 \%$ saline solution with $100 \mu \mathrm{g} / \mathrm{mL}$ penicillin at room temperature.

Ovarian cortical tissue was identified and divided into small pieces of approximately $1 \mathrm{~mm}^{3}$ which were then separated into three groups: control (prior transplantation for histological analysis), freshly transplanted (FX): transplanted without vascular reanastomosis under the renal capsule of the kidney (five fragments per recipient), and cryopreserved (CX) (also transplanted after 15 days of cryopreservation). The fragments were kept in Minimum Essential Medium (MEM) until the time of transplantation, not exceeding the five-hour time limit from harvest or thawing to transplantation. 


\section{Cryopreservation of cortical pieces}

The pooled cortical pieces were used for the cryopreserved group. The vitrification solution (VS) consisted of 3 mols/L dimethyl sulfoxide (DMSO) in Minimum Essential Medium (MEM) supplemented with $0.25 \mathrm{M}$ sucrose (SUC) and $10 \%$ fetal calf serum (FCS). After that moment, the samples were exposed in $1.8 \mathrm{~mL}$ of VS for 5 minutes and the solution excess was withdrawn with sterile gauze, placed on a metal bucket surface partially immersed in liquid nitrogen $\left(\mathrm{LN}_{2}\right)$ and then vitrified. After that, the sample was transferred (with nitrogen-cooled clamp) to cryotubes for storage in $\mathrm{LN}_{2}\left(-196^{\circ} \mathrm{C}\right)$ (Carvalho et al., 2011).

After 2 weeks the samples were thawed at room temperature (approximately $25^{\circ} \mathrm{C}$ ) for 1 min and then immersed in a $37^{\circ} \mathrm{C}$ water bath for $5 \mathrm{~s}$. DMSO was removed from the ovarian fragment by three consecutive washes for 5 min in MEM supplemented with 10\% FCS and decreasing sucrose concentrations $(0.50,0.25$ and $0 \mathrm{~mol} / \mathrm{L})$. Finally, the cortical pieces were xenotransplanted in the recipients (Praxedes et al., 2018).

\section{Mice recipients}

Immunodeficient mice of the C57BL/6 SCID $(n=15)$ and Balb-C NUDE $(n=15)$ lineages, ageing between 20-24 weeks were housed in sterile mini-cages and maintained under a light/dark cycle of 12 hours at $22{ }^{\circ} \mathrm{C}$ and fed ad libitum. For surgical procedures 5 animals/lineage were used to perform the fresh xenotransplantation (FX) and 10 animals/lineage for cryopreserved xenotransplantation (CX).

\section{Xenotransplantation procedure}

Recipients were anesthetized with 2.5\% 2,2,2-tribromoethanol at the dose of $18 \mathrm{ml} \mathrm{kg}^{-1}$ (SCID) and $20 \mathrm{ml} \mathrm{kg}^{-1}$ (NUDE) by intraperitoneal administration. Dosages were established from previous experiments (Pimentel et al., 2017).

After bilateral ovariectomy, five pieces of the pooled ovarian tissue were gently transplanted under the left renal capsule of the recipients and, in the absence of abnormalities the abdominal cavity was closed. After procedure completion, the animals were placed in mini-cages at $37^{\circ} \mathrm{C}$ until complete anesthetic recovery.

\section{Assessment of ovarian activity}

Before receiving the ovarian fragments, the recipients had their estrous cycle monitored for 90 days and thus functioned as a control of themselves after the xenotransplantation.

Five days after the surgical procedure, vaginal washing was performed in the recipients to evaluate the estrous cycle every 12 hours for 60 days. The mice were gently restrained and washed intravaginally with a $20 \mu \mathrm{L}$ micropipette filled with $0.9 \%$ saline and vaginal washes were evaluated under inverted light microscopy and without staining, in a 20x magnification. Classification of the estrous cycle phase through vaginal washing was based on previously established criteria (Cooper, 1993; Byers et al., 2012).

\section{Hormonal assay}

The animals were intraperitoneally anesthetized with 2,2,2-tribromoethanol. The general anesthesia and its effectiveness were confirmed by the absence of foot reflex, cardiac puncture was then performed according to Hoff (2000). The total blood volume collected in the animals was approximately $1 \mathrm{~mL}$. After this procedure the animals were euthanized. The death was confirmed by checking for the absence of vital signs such as heartbeat and respiratory movements. Blood from each animal was centrifuged at $2000 \mathrm{~g}$ for 10 minutes at room temperature to obtain the plasma. The samples were then analyzed in duplicate for determining 17ß-estradiol concentrations using amplified chemiluminescence using an 
immunoassay system (Vitros Eci/EciQ Immunodiagnostic System, Johnson and Johnson) according to the manufacturer's instructions and following the methods of Bartoskova et al. (2014).

\section{Histological processing and evaluation}

After death, the transplants were recovered and immediately immersed in $4 \%$ paraformaldehyde solution buffered with phosphate solution $(\mathrm{pH} 7.2)$ for 24 hours, subsequently dehydrated, diaphanized and embedded in paraffin, then sectioned semi-serially at a thickness of $5 \mu \mathrm{m}$, with one section mounted every $60 \mu \mathrm{m}$. Next, they were stained with hematoxylin-eosin (HE) and Masson's trichrome (MT).

The ovarian tissue was assessed according the integrity of its parenchyma, quality and classification of preantral and antral follicles, as well as vascularization and aggregation of stromal cells. The follicles were classified according to morphology and number of granulosa cell layers surrounding the oocyte as primordial, primary, secondary and antral (Kumari et al., 2017). Larger antral follicles were aspirated during withdrawal.

\section{Stereological vascularization analysis}

One image from each section of the xenotransplantation was randomly captured on 10X objective, totaling 10-12 photomicrographs. These were overlaid by a test system used to measure the volume of each fragment by the Cavallieri's principle, as described by Noorafshan et al. (2013).

The volume of the xenotransplanted ovary fragment was determined using the following Formula 1:

$$
\text { Volume }=\sum p \times a(p) \times T
$$

where $\Sigma p$ is the sum of points that overlaps the image; $a(p)$ is the area associated with each point; and $T$ is the distance between each section of the sample.

Five fields from the same sections were randomly photographed in the 40X objective using a microscope coupled to a camera (LEICA DM500) to determine the volume density and area of blood vessels. A test system was superimposed on the images for quantification (Figure 1).

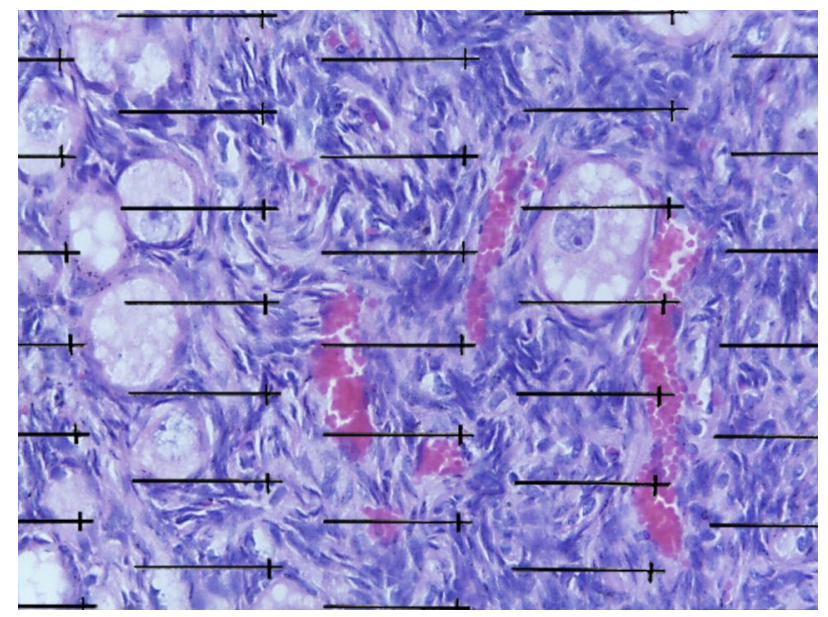

Figure 1. Ovary fragment of xenotransplanted goat fetus in the renal subcapsular region of mice withoverlap of the grid used to determine the volume surface density of the blood vessels of the fragment. Scale bar $=10 \mu \mathrm{m}$. HE staining. 
The volume density ( $\mathrm{V} v$ ) of the vessels in the fragments of the two groups was calculated by the following Formula 2:

$$
V v=(\Sigma p(\text { Vessels })) /(\Sigma p(\text { total }))
$$

where $\Sigma p($ Vessels) is the sum of points that touch the blood vessels; and $\Sigma p($ total) is the total points of the test system.

The area density (Sv) was measured by the Formula 3:

$$
S v=2 I /(\Sigma p \times I(p))
$$

where I corresponds to the number of line intersections in the vessels; I ( $p$ ) is the length of the line; and $\Sigma p$ is the sum of the points that touch the xenotransplanted ovarian tissue.

The total surface of the vessels $\left(\mu \mathrm{m}^{2}\right)$ was determined by multiplying the Sv by the xenotransplanted fragment volume.

\section{Analysis of results}

Data were tabulated and submitted to descriptive statistics. The chi-square test $\left(\chi^{2}\right)$ was used for the data obtained in the analyzes of the follicular proportions. For comparing counting data (absolute values) between treatments, the data were previously submitted to assumptions (Kolmogorov-Smirnov, Shapiro-Wilk, Levene, Lilliefors) after verifying heteroscedasticity and non-Gaussian distribution, the samples were analyzed by the KruskalWallis test followed by a Dunn post-hoc test. The software package used was the STATISTICA ${ }^{\circledR}$ 8 program.

Mean duration of estrous cycle phases, biochemical data and hormone dosage were compared by ANOVA followed by the Tukey test. The development data of the transplanted tissue were put into percentage, with BioEstat 5.0 and Microsoft Office Excel 14.0 being used for this purpose.

Stereology data were analyzed using the Mann-Whitney test using Graph Prism version 3.05 .

All comparisons were performed according to the experimental groups with probability level of $5 \%$.

\section{Results}

\section{Macroscopic findings}

Transplanted tissue development was observed immediately after recovery, presenting normal appearance as well as several antral follicles on its surface. This observation was further confirmed by histological evaluation, thus confirming that there was $100 \%(n=05 / 05)$ development of the transplanted fresh tissue, and $80 \%(n=8 / 10)$ after cryopreservation and xenotransplantation in the females of both lineages: C57BL6 SCID and BALB/C NUDE (Figure 2). In the other $20 \%$ of the tissue after cryopreservation and xenotransplantation, only ovarian fibroblasts were observed. 

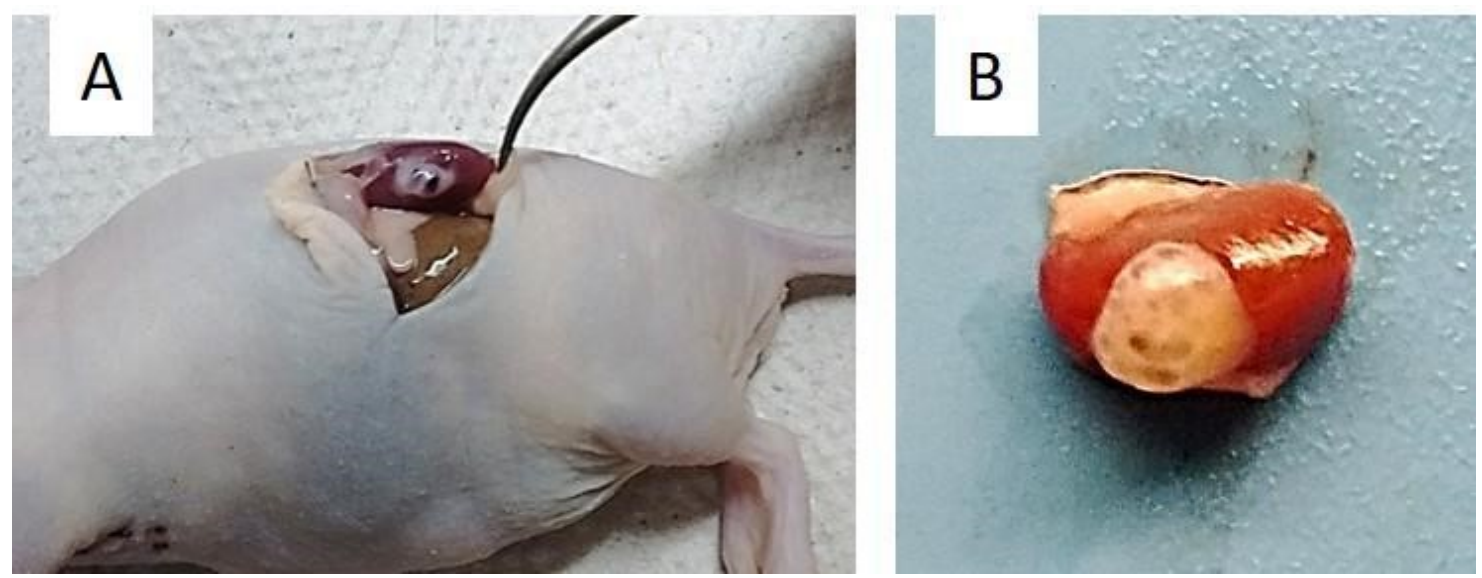

Figure 2. Fragment of ovarian cortex of goat fetus collected after 65 days of xenotransplantation immunosuppressed recipients (A), demonstrating ovarian development under renal capsule (B).

\section{Microscopic findings}

\section{Vaginal lavage evaluation}

Considering the mice lineages used, all recipients presented a return to ovarian activity rate with complete estrous cycle after fresh transplantation, and $80 \%(n=8 / 10)$ after cryopreservation and xenotransplantation in the females of both lineages: C57BL6 SCID and $\mathrm{BALB} / \mathrm{C}$ NUDE. The four phases of the estrous cycle were observed in all experimental animals (Figure 3), but some of these were more prolonged in the transplanted animals (Table 1, $p<0.05$ ). The onset of this activity after xenotransplantation was on average $13 \pm 6$ days from the FX group and $17 \pm 9$ days from the CX group in the C57BL6 SCID females, and $4 \pm 2$ days from the FX group and $10 \pm 5$ days from the CX group in the BALB/C NUDE females, observing irregularity in the estrous cycle of transplanted animals.

Table 1. Mean and standard deviation (hours) of the phase durations of the first estrous cycle of the different experimental groups.

\begin{tabular}{|c|c|c|c|c|c|}
\hline \multirow{2}{*}{\multicolumn{2}{|c|}{ Experimental groups }} & \multicolumn{4}{|c|}{ Estrous cycle stages } \\
\hline & & Proestrus & Estrus & Metaestrus & Diestrus \\
\hline & Control & $12.0 \pm 0.7^{\mathrm{aB}}$ & $96.0 \pm 1.9^{\mathrm{aA}}$ & $12.0 \pm 0.0^{\mathrm{aB}}$ & $48.0 \pm 1.2^{\mathrm{bB}}$ \\
\hline \multirow{3}{*}{$\begin{array}{c}\text { C57BL6 } \\
\text { SCID }\end{array}$} & Fresh & $24.0 \pm 1.0^{a B}$ & $32.0 \pm 0.0^{\mathrm{bA}}$ & $12.0 \pm 0.0^{\mathrm{aA}}$ & $160.0 \pm 12.3^{\mathrm{aA}}$ \\
\hline & Cryo & $36.0 \pm 1.7^{\mathrm{aA}}$ & $68.0 \pm 12.5^{\mathrm{aA}}$ & $12.0 \pm 0.0^{\mathrm{aA}}$ & $172.0 \pm 2.5^{\mathrm{aA}}$ \\
\hline & Control & $72.0 \pm 0.9^{\mathrm{aA}}$ & $48.0 \pm 0.9^{\mathrm{bB}}$ & $24.0 \pm 0.8^{\mathrm{aA}}$ & $72.0 \pm 1.1^{\mathrm{bA}}$ \\
\hline \multirow{2}{*}{$\begin{array}{l}\text { BALB/C } \\
\text { NUDE }\end{array}$} & Fresh & $40.0 \pm 1.5^{\mathrm{bA}}$ & $36.0 \pm 0.0^{\mathrm{bA}}$ & $12.0 \pm 0.0^{\mathrm{bA}}$ & $120.0 \pm 3.0^{\mathrm{aB}}$ \\
\hline & Cryo & $25.0 \pm 1.1^{\mathrm{bA}}$ & $60.0 \pm 4.2^{\mathrm{aA}}$ & $12.0 \pm 0.0^{\mathrm{bA}}$ & $111.0 \pm 4.3^{\mathrm{aB}}$ \\
\hline
\end{tabular}

Lower case letters indicate comparison between treatments within the same lineage. Upper case letters indicate comparison between the same treatment among different transplanted lineages. 

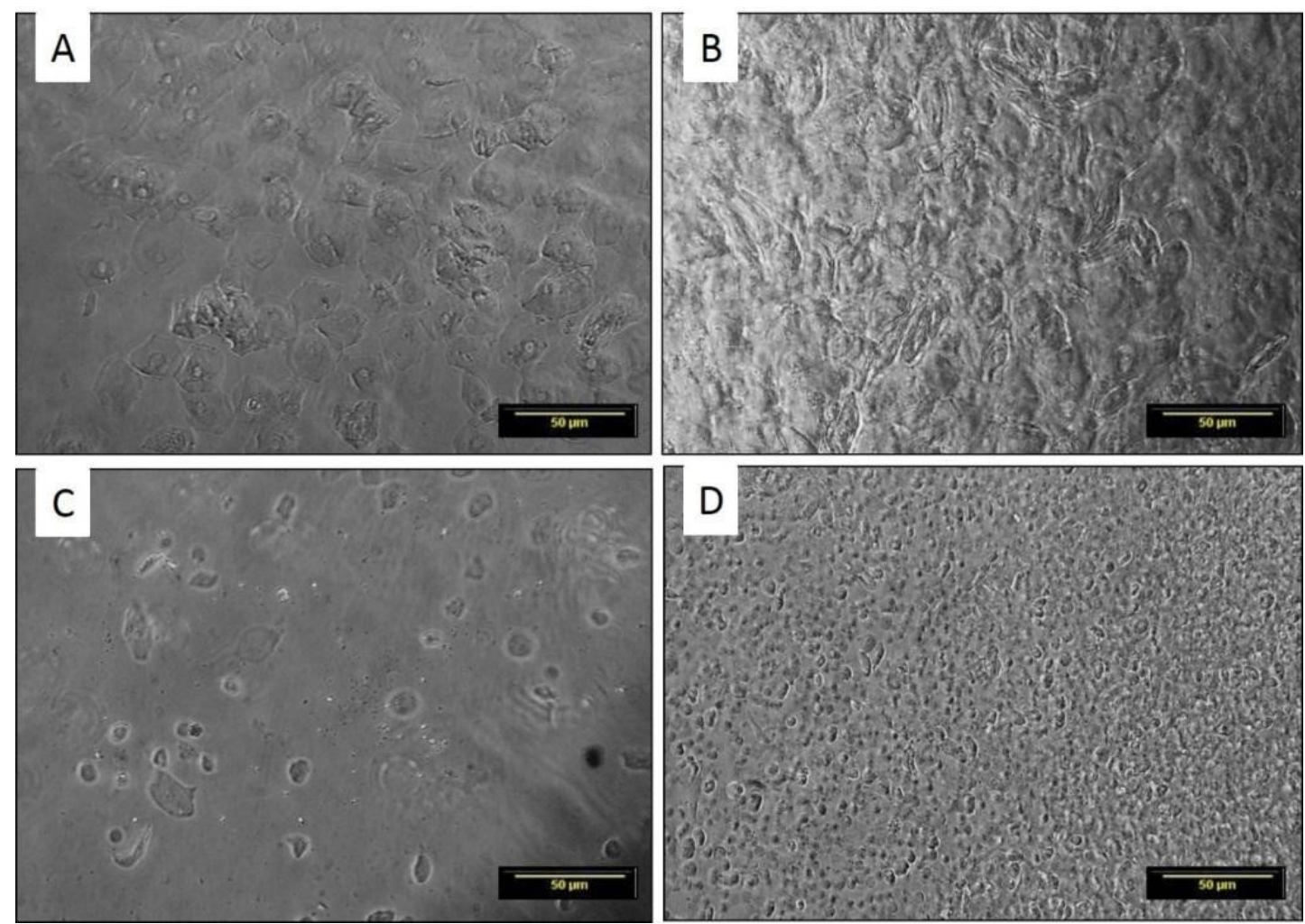

Figure 3. Cytological pattern of vaginal lavage of immunosuppressed mice after xenotransplantation. (A) proestrus - presence of rounded and nucleated epithelial cells (basal and parabasal); (B) estrus - keratinized cells in greater proportion; (C) metaestrus - reduction in the amount of keratinized cells, some leukocyte cells and appearance of some epithelial cells; (D) diestrous - small proportion of epithelial and keratinized cells and large amount of leukocyte cells. Scale bar: $50 \mu \mathrm{m}$. Increased by $20 \mathrm{x}$.

\section{Morphology of preantral and antral follicles}

Follicles were observed at all development stages (Figure 4). Therefore, both lineages and the chosen recipient site allowed follicular development in the antral phase after both fresh and cryopreservation transplantation. Upon observation the atresic follicles presented degeneration of the oocytes accompanied by rupture of granulosa cell layers and pycnotic nuclei.
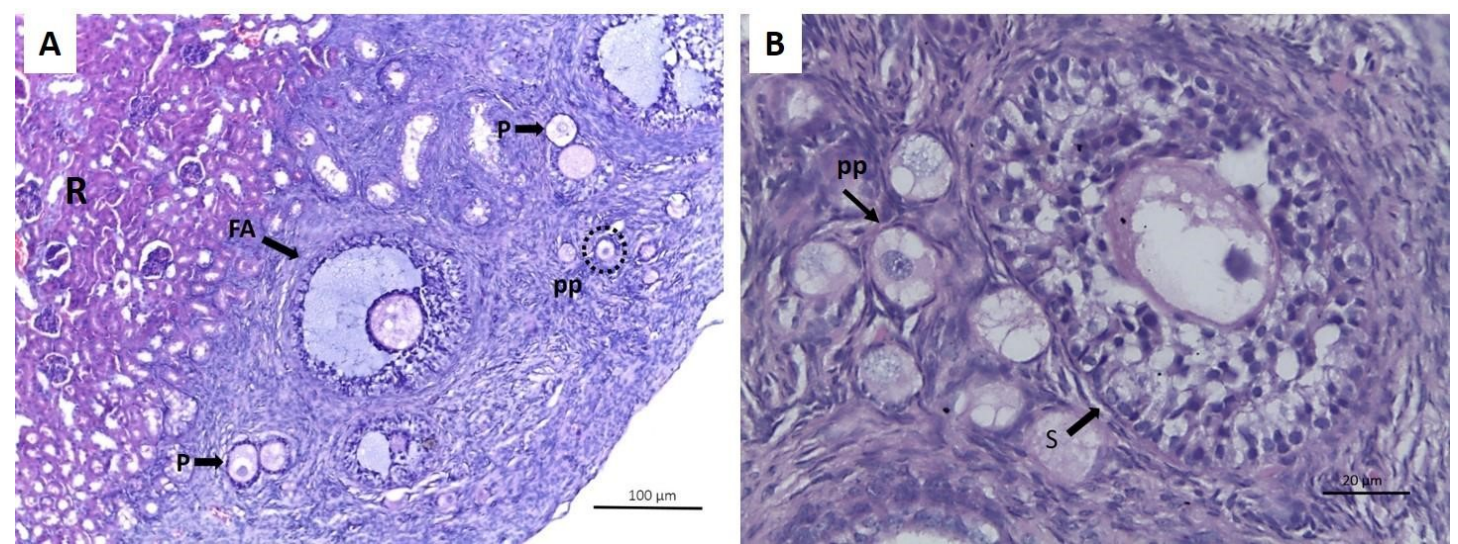

Figure 4. Photomicrography of mongrel goat fetus ovary after ovarian xenotransplantation in immunosuppressed C56BL6 SCID receptors. (A) primordial follicles (pp), antral follicle (FA), primary follicle $(P)$, renal region of the recipient $(R)$. Increase by 10x; (B) secondary follicle $(S)$, primordial follicle $(p p)$, Hematoxylin-Eosin staining (HE). Increased by 40x. 


\section{Proportions of follicular stages}

Complete follicular development was observed after fresh and cryopreserved ovarian xenotransplantation in both lineages. When compared to control, a decrease of preantral follicles of both treatments were observed in both lineages (Table 2, $p<0.05$ ).

Table 2. Follicular proportion (\%) of fetal ovary xenotransplantation under the renal capsule of C56BL6 SCID and BALB-C NUDE mice.

\begin{tabular}{|c|c|c|c|c|c|c|c|}
\hline \multirow{2}{*}{\multicolumn{2}{|c|}{ Treatments }} & \multirow{3}{*}{$\begin{array}{c}\begin{array}{c}\text { Total } \\
\text { follicles }\end{array} \\
n=1288\end{array}$} & \multicolumn{5}{|c|}{ FOLLICULAR CATEGORY } \\
\hline & & & \multirow{2}{*}{$\begin{array}{l}\text { Primordial } \\
88.3 \pm 2.4^{\text {a }}\end{array}$} & \multirow{2}{*}{$\begin{array}{c}\text { Primary } \\
11.7 \pm 2.4^{b}\end{array}$} & \multirow{2}{*}{$\begin{array}{c}\text { Secondary } \\
0 \pm 0.0^{b}\end{array}$} & \multirow{2}{*}{$\begin{array}{c}\text { Initial Antral } \\
0 \pm 0.0^{c}\end{array}$} & \multirow{2}{*}{$\begin{array}{l}\text { Antral } \\
0 \pm 0.0^{c}\end{array}$} \\
\hline $\begin{array}{l}\text { Fresh } \\
\text { Ovary }\end{array}$ & FO & & & & & & \\
\hline \multirow{2}{*}{ Fresh } & SCID & $=2757$ & $47.7 \pm 5.3^{\mathrm{bA}}$ & $27.6 \pm 6.4^{\mathrm{bA}}$ & $13.3 \pm 4.7 \%^{\mathrm{aA}}$ & $7.1 \pm 1.9^{\mathrm{aA}}$ & $0.5^{\mathrm{aA}}$ \\
\hline & NUDE & $=2599$ & $46.6 \pm 7.1 \mathrm{bA}$ & $30.5 \pm 5.3^{\mathrm{aA}}$ & $16.7 \pm 3.4^{\mathrm{aA}}$ & $3.7 \pm 0.8^{\mathrm{bA}}$ & $0.7^{\mathrm{bB}}$ \\
\hline \multirow{2}{*}{ Cryo } & SCID & $n=200$ & $46.6 \pm 10^{\mathrm{bA}}$ & $25.1 \pm 5 \%$ bA & $22.9 \pm 7^{\mathrm{aA}}$ & $3.8 \pm 4.0^{\mathrm{bA}}$ & $1.5 \pm 3.0^{\mathrm{bB}}$ \\
\hline & NUDE & $\mathrm{n}=90$ & $38.7 \pm 33^{b A}$ & $39.5 \pm 26^{\mathrm{aA}}$ & $12.4 \pm 10^{\mathrm{aA}}$ & $4.4 \pm 6.0 \mathrm{abA}$ & $5.1 \pm 8.0^{a A}$ \\
\hline
\end{tabular}

Lower case letters compare the control group with each treatment. Uppercase letters compare the treatments between lines (i.e. fresh SCID x cryo SCID).

\section{Vascular supply for transplanted tissue}

Sixty-five (65) days after the xenotransplantation, the vascular supply provided by the recipient's kidney to the ovarian cortex fragments of the donors was considered morphologically similar to that existing in the in situ ovary of the donors, with revascularization occurring in $100 \%$ of the fresh transplants and in $80 \%$ of the cryopreserved transplants of both recipient lineages (C57BL6 SCID and BALB/C NUDE), with the same proportions being found in the return of the ovarian activity of these animals. Blood vessels were histologically observed in the recovered transplants (Figure 5).

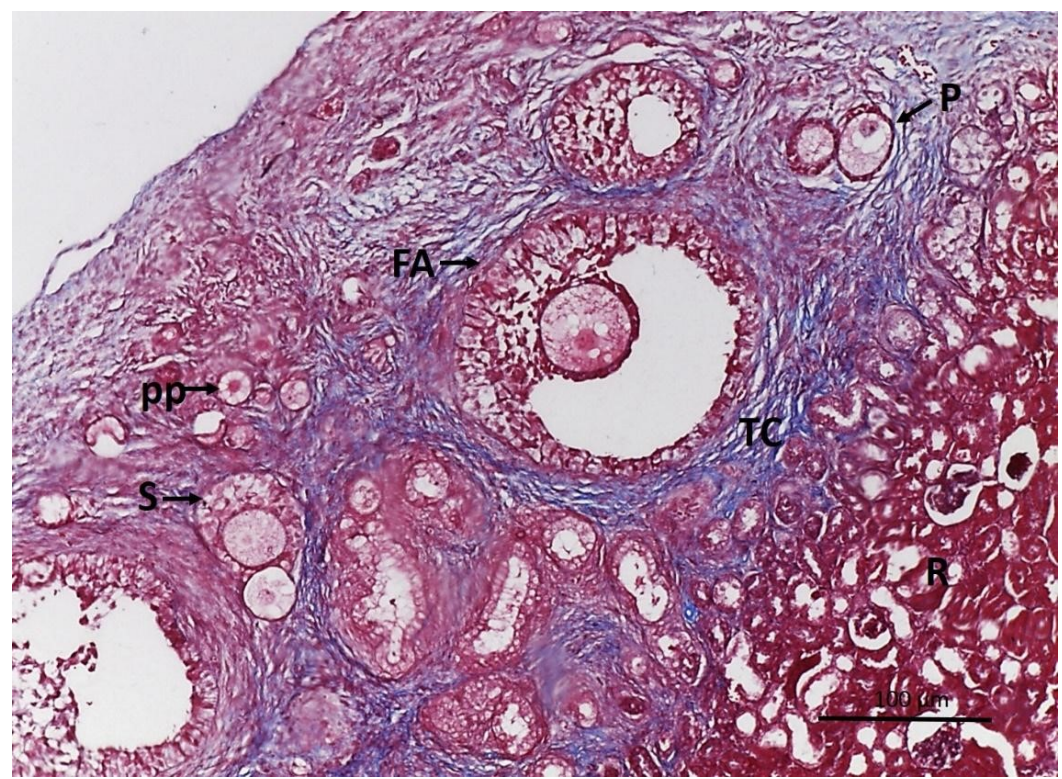

Figure 5. Photomicrography of goat fetus ovary after ovarian xenotransplantation in immunosuppressed BALB-C NUDE receptors. Antral follicle (FA), secondary follicle (S), primary follicle (P), primordial follicle (pp). Note the cortical tissue integration of the ovary and the renal parenchyma of the operated recipient (R) and connective tissue (TC), Masson's trichrome staining (MT). Increased by 10x.

\section{Stereological study of blood vessels}

After counting all the points and intersections of the test system, it was found that the volume of the fragments, the volume density and the surface density presented a difference $(p<0.01)$ between the treatments of the Balb-c NUDE lineage, as shown in Table 3. 
Table 3. Effect of vitrification on ovarian xenotransplant volume, volume density (Vv), vessel area (Sv).

\begin{tabular}{ccccc}
\hline Lineage & Treatments & Volume $\left(\mathbf{m m}^{3}\right)$ & $\mathbf{V v}(\mathbf{\%})$ & \multicolumn{1}{c}{ Sv $\left(\boldsymbol{\mu m}^{-1}\right)$} \\
\cline { 2 - 5 } C57BL6 SCID & FX & $34825.7^{\mathrm{a}}$ & $12^{\mathrm{a}}$ & $36.18^{\mathrm{a}}$ \\
\cline { 2 - 5 } & $\mathrm{CX}$ & $13038.7^{\mathrm{a}}$ & $5.71^{\mathrm{a}}$ & $5.93^{\mathrm{a}}$ \\
\hline \multirow{2}{*}{ BALB/C NUDE } & FX & $35692.2^{\mathrm{a}}$ & $16^{\mathrm{a}}$ & $68.39^{\mathrm{a}}$ \\
\cline { 2 - 5 } & $\mathrm{CX}$ & $7839.98^{\mathrm{b}}$ & $3.33^{\mathrm{b}}$ & $3.46^{\mathrm{b}}$ \\
\hline
\end{tabular}

Lowercase letters compare treatments of the same lineage. FX: Fresh Xenotransplantation; CX: Xenotransplantation after cryopreservation.

\section{Hormonal assessment}

Estradiol hormone assays from the recipient mice were performed based at the end time of the experiment and, in C57BL6 SCID recipients, the levels ranged from 37.59 to $56.40 \mathrm{pg} / \mathrm{ml}$ submitted to FX group, whereas it ranged from 35.26 to $56.60 \mathrm{pg} / \mathrm{ml}$ in CX group. In the FX group Balb/c NUDE recipients, the values ranged from 34.98 to $50.21 \mathrm{pg} / \mathrm{ml}$, and those from the CX group ranged from 40.60 to $51.23 \mathrm{pg} / \mathrm{ml}$ (Table $4, \mathrm{p}>0.05$ ).

Table 4. Estradiol hormone dosage after ovary xenotransplantation of goat fetus under the renal capsule of C56BL6 SCID and BALB-C NUDE mice.

\begin{tabular}{ccc} 
Lineage & Treatments & Dosage $(\mathbf{p g} / \mathbf{m L})^{\mathbf{n s}}$ \\
\multirow{2}{*}{ C57BL6 SCID } & Fresh & $48.04 \pm 8.00$ \\
\cline { 2 - 3 } & Cryo & $42.48 \pm 5.93$ \\
\hline \multirow{2}{*}{ BALB/c NUDE } & Fresh & $47.07 \pm 8.37$ \\
\cline { 2 - 3 } & Cryo & $45.23 \pm 4.06$ \\
\hline
\end{tabular}

nsthere were no differences between the performed comparisons ( $p>0.05)$.

\section{Discussion}

The present study provides relevant information for rescuing preantral follicles in ovaries of goat fetuses after xenotransplantation. The use of animal germplasm is growing on the part of researchers and laboratories interested to develop economically and ecologically valuable animals. Some individuals may find themselves in situations of vulnerability such as prey or hunting due to anthropic action. Investigations with xenotransplantations were performed in domestic mammals (Gosden et al., 1994; Barros et al., 2014; Tahaei et al., 2015; Santos et al., 2016) and wild ones (Wiedemann et al., 2012; Praxedes et al., 2018).

The return of ovarian activity in the recipients and the presence of a high number of primordial follicles as well as antral follicles after xenotransplantation confirmed the hypothesis that this biotechnique represents a promising tool for recovering ovarian function and to elucidate revascularization mechanisms in fresh or cryopreserved tissues (Youm et al., 2014). However, preservation of fertility using ovarian tissue transplants is still in the experimental phase (Lee et al., 2015) and is slowly being adapted not only for animals (Ayuandari et al., 2016). Already being widely used in humans (Mofarahe et al., 2020; Mohammadi et al., 2020).

Tissue adhesion and the presence of vascularization were macroscopically observed in all treatments, that demonstrated the efficacy of growth and revascularization during the evaluated transplant time. Reperfusion played an important role in preventing follicle depletion during the first few days to one week after transplantation (Soleimani et al., 2011). During this phase, ischemia and hypoxia occurs until the formation of new blood vessels within both the transplantation and the surrounding tissue (Van Eyck et al., 2010), thus, with complete revascularization the oxygen and nutrients of the surrounding tissue are diffused into the transplanted tissue, restoring it.

The efficiency of this blood reperfusion had a reflex in the estrus observation in the recipients. Determining the estrous cycle is of paramount importance in xenotransplantation procedures, since they serve as an indirect evidence of the hormonal changes resulting from readapting the transplanted tissues and are reflected in the cycle. In this study, irregularities in 
the estrous cycle of the animals after xenotransplantation were observed in both treatments when compared to the control, with longer phases (in the estrus and diestrus of the Balb/c NUDE and in the estrus in the C57BL6 SCID mice recipients) and other shorter phases (proestrus and metaestrus of the Balb/c NUDE recipients and in the diestrus of the C57BL6 SCID recipients). It is believed that the physiological state of the recipients may influence transplantation and/or follicular survival. In some ovarian transplantation studies, bilateral ovariectomized females were performed due the consecutive release of higher concentrations of gonadotrophins after ovariectomy (Gosden et al., 1994; Wolvekamp et al., 2001). This initial hormonal decompensation after ovariectomy possibly caused irregularities in the estrous cycle after transplantation, since the hypothalamic-pituitary-gonadal (HPG) axis of the recipients was not yet adapted to the newly incorporated gonad.

In relation to follicular development, many culture systems were developed in the last decades for improvement of primordial follicle activation and preantral follicle growth by autotransplantation (Santos et al., 2009) and in vitro culture until they are able to use in vitro fertilization in goats (Magalhães et al., 2011). Similar results were observed here, once the development of the follicles until the antral stage was verified. During fetal life, primordial follicles are activated around the $73^{\text {rd }}$ day post conception and antral follicles are shown from the beginning of the last third of gestational life with small changes in the folliculogenesis kinetics in the preantral phase (Bezerra et al., 1998). The possibility of development and differentiation prior to interrelating the HPG axis and the early ovarian responsiveness to gonadotrophins in goat fetuses were recently considered in fetus of this species (Kumari et al., 2017), with possibilities mainly being plausible when the gonadotrophin source comes from another species like that presented in this study.

The kinetics of follicular development were evidenced when follicular proportions were observed between the different treatments and lineages, with a follicular right shift being observed. A phenomenon characterized by a decrease in the number of primordial follicles and a gradual increase of primary, secondary and antral follicles due to follicle activation and follicular growth after xenotransplantation (Santos et al., 2016), showing that in vivo culture by fetal goat ovary xenotransplantation was efficient and allowed for normal follicular development.

The number of viable follicles was not different between groups, the only exception was in case of antral follicles between FX and CX group of the C57BL6SCID lineage. It is known that cryogenic injuries can affect follicular development, reducing cellular respiration, increasing DNA degeneration and releasing intracellular material (Laschke et al., 2003). However, the current consensus is that ischemia prior to transplantation can lead to damage induced by cryopreservation, which is the main cause of follicular loss (González et al., 2012). In this study, there was a reduction in follicular density after vitrification, but this did not prevent the existing follicles in both mice lineages from developing to antral follicles, which were probably favored by less competition for nutrients.

The renal subcapsular region offers several advantages for maintaining transplanted tissue as a recipient site: the same embryological origin of the reproductive tract and the potential vascular support around 20 to $25 \%$ of the cardiac output (Christie and Bjorling, 2003). For this study, the renal subcapsular region was chosen as the recipient site of the ovarian tissues by this site to prevent the extrusion of the ovarian tissue into the abdominal cavity. Another reason for choosing this site was that the renal parenchyma provides better vascularization, since it avoids extending the distance of the transplanted tissue from the blood supply, thus enabling faster follicular activation after transplantation (Aerts et al., 2010).

The data presented by the stereological evaluation showed that the volume of the fragments, the volume density and the vessel area of the Balb/c NUDE lineage was lower in the transplanted ovarian tissue after cryopreservation when compared to the fresh transplanted tissue $(p<0.01)$. Better results were found in the C57BL6SCID lineage, with no difference $(p>0.05)$ between treatments, demonstrating that these mice may be a better recipient for transplanted tissues after cryopreservation compared to Balb/c NUDE. Stereology studies were essential to demonstrate the xenotransplantation efficacy for revascularizing the fragments in the different treatments. The findings on the 
quantification of ovarian follicles after transplantation associated with vascularization conferred the best performance for C57BL6 SCID lineage recipients.

Estradiol levels in the mice after goat fetus ovarian xenotransplantation was found to be within the range expected for the species and lineage (Ingberg et al., 2012). After an ischemic, the fetal ovary was able to revascularize under the renal capsule and possibly induced reactivation of the hypothalamus-hypophysis-gonadal axis of the recipients, and thereby allowing the massive production of $17 \beta$-estradiol by the implanted fragment which helped in follicular development. This hormone is considered the most potent natural estrogen produced by the ovaries in most species. It is produced predominantly by the aromatization of testosterone by granulosa cells (GC) of the ovarian follicle. In the follicular phase of the cycle, the increased rate of secretion of FSH induces expression of the aromatase enzyme in GC. As a result, estrogen production in the follicle increases rapidly. The rising of FSH serum concentration leads also to an accelerated growth of the follicle largely due to the rapid secretion and accumulation of follicular fluid (FF). The FF is also formed by GC (Bentov et al., 2016).

\section{Conclusion}

The xenotransplantation of goat fetal ovaries, freshly or after their cryopreservation allowed, without the use of hormonal protocols, the survival, growth and development of antral follicles.

Considering the importance of transplantation studies for preserving fertility and shortening capacity between generations, the xenotransplantation technique applied in this work may provide an in vivo model to study population and follicle development from fetal ovaries in several species, including wild goats. In addition, in spite of reducing the number of available ovarian follicles, ovarian fetal tissue xenotransplantation still provides satisfactory follicular development and restores endocrine function in the recipients, in which all the estrous cycle phases were observed.

\section{Acknowledgements}

This research did not receive any specific funding.

\section{References}

Aerts JM, Martinez-Madrid B, Leroy JL, Van Aelst S, Bols PE. Xenotransplantation by injection of a suspension of isolated preantral ovarian follicles and stroma cells under the kidney capsule of nude mice. Fertil Steril. 2010;94(2):708-14. http://dx.doi.org/10.1016/j.fertnstert.2009.03.055. PMid:19423102.

Ayuandari S, Winkler-Crepaz K, Paulitsch M, Wagner C, Zavadil C, Manzl C, Ziehr SC, Wildt L, HoferTollinger $S$. Follicular growth after xenotransplantation of cryopreserved/thawed human ovarian tissue in SCID mice: dynamics and molecular aspects. J Assist Reprod Genet. 2016;33(12):1585-93. http://dx.doi.org/10.1007/s10815-016-0769-2. PMid:27465301.

Baguisi A, Behboodi E, Melican DT, Pollock JS, Destrempes MM, Cammuso C, Williams JL, Nims SD, Porter CA, Midura P, Palacios MJ, Ayres SL, Denniston RS, Hayes ML, Ziomek CA, Meade HM, Godke RA, Gavin WG, Overström EW, Echelard Y. Production of goats by somatic cell nuclear transfer. Nat Biotechnol. 1999;17(5):456-61. http://dx.doi.org/10.1038/8632. PMid:10331804.

Barros FFPC, Teixeira PPM, Silva MAM, Silva ASL, Medeiros RM, Coelho CMM, Vicente WRR. Xenotransplante em camundongos imunossuprimidos coletado por meio de ovariectomia unilateral total videolaparoscópica em ovelha. Rev Bras Reprod Anim. 2014;38:121-6.

Bartoskova A, Ondrackova P, Leva L, Vitasek R, Novotny R, Janosovska M, Faldyna M. The effects of in vitro exposure to progesterone and estradiol- $17 \beta$ on the activity of canine neutrophils. Vet Med (Praha). 2014;59(4):202-9. http://dx.doi.org/10.17221/7481-VETMED. 
Bentov Y, Jurisicova A, Kenigsberg S, Casper RF. What maintains the high intra-follicular estradiol concentration in pre-ovulatory follicles? J Assist Reprod Genet. 2016;33(1):85-94. http://dx.doi.org/10.1007/s10815-015-0612-1. PMid:26552664.

Bertolini LR, Meade H, Lazzarotto CR, Martins LT, Tavares KC, Bertolini M, Murray JD. The transgenic animal platform for biopharmaceutical production. Transgenic Res. 2016;25(3):329-43. http://dx.doi.org/10.1007/s11248-016-9933-9. PMid:26820414.

Bezerra MB, Rondina D, Lima AKF, Oliveira LC, Cecchi R, Lucci CM, De Figueiredo JR. Aspectos quantitativos e qualitativos da foliculogênese pré-natal na espécie caprina. Ciênc Anim. 1998;8(2):47-56.

Byers SL, Wiles MV, Dunn SL, Taft RA. Mouse estrous cycle identification tool and images. PLoS One. 2012;7(4):e35538. http://dx.doi.org/10.1371/journal.pone.0035538. PMid:22514749.

Carvalho AA, Faustino LR, Silva CMG, Castro SV, Luz HKM, Rossetto R, Lopes CAP, Campello CC, Figueiredo JR, Rodrigues APR, Costa APR. Influence of vitrification techniques and solutions on the morphology and survival of preantral follicles after in vitro culture of caprine ovarian tissue. Theriogenology. 2011;76(5):933-41. http://dx.doi.org/10.1016/j.theriogenology.2011.04.024. PMid:21719087.

Christie BA, Bjorling DE. Kidney. In: Slatter DH, editor. Textbook of small animal surgery. Philadelphia: Elsevier; 2003. Vol. 1, p. 1698-713.

Comizzoli P. Biobanking efforts and new advances in male fertility preservation for rare and endangered species. Asian J Androl. 2015;17(4):640-5. http://dx.doi.org/10.4103/1008-682X.153849. PMid:25966625.

Comizzoli P, Wildt DE. Mammalian fertility preservation through cryobiology: value of classical comparative studies and the need for new preservation options. Reprod Fertil Dev. 2013;26(1):91-8. http://dx.doi.org/10.1071/RD13259. PMid:24305181.

Commin L, Buff S, Rosset E, Galet C, Allard A, Bruyere P, Joly T, Guérin P, Neto V. Follicle development in cryopreserved bitch ovarian tissue grafted to immunodeficient mouse. Reprod Fertil Dev. 2012;24(3):461-71. http://dx.doi.org/10.1071/RD11166. PMid:22401278.

Cooper R. Monitoring of estrous cycle in the laboratory rodent by vaginal lavage. In: Chapin RE, Heindel J, editors. Methods in toxicology. Orlando: Academic Press; 1993. Vol. 3, Part B: female reproductive toxicology, pp. 45-56.

Donfack NJ, Alves KA, Alves BG, Rocha RMP, Bruno JB, Lima LF, Lobo CH, Santos RR, Domingues SFS, Bertolini M, Smitz J, Rodrigues APR. In vivo and in vitro strategies to support caprine preantral follicle development after ovarian tissue vitrification. Reprod Fertil Dev. 2018;30(8):1055-65. http://dx.doi.org/10.1071/RD17315. PMid:29332622.

Durawo C, Zindove TJ, Chimonyo M. Influence of genotype and topography on the goat predation challenge under communal production systems. Small Rumin Res. 2017;14:115-20. http://dx.doi.org/10.1016/j.smallrumres.2017.01.015.

Fonseca JF, Souza-Fabjan JMG, Oliveira MEF, Leite CR, Nascimento-Penido PMP, Brandão FZ, Lehloenya KC. Nonsurgical embryo recovery and transfer in sheep and goats. Theriogenology. 2016;86(1):14451. http://dx.doi.org/10.1016/j.theriogenology.2016.04.025. PMid:27177961.

Gastal GDA, Hamilton A, Alves BG, de Tarso SGS, Feugang JM, Banz WJ, Apgar GA, Nielsen CK, Gastal EL. Ovarian features in white-tailed deer (Odocoileus virginianus) fawns and does. PLoS One. 2017;12(5):e0177357. http://dx.doi.org/10.1371/journal.pone.0177357. PMid:28542265.

González C, Boada M, Devesa M, Veiga A. Concise review: fertility preservation: an update. Stem Cells Transl Med. 2012;1(9):668-72. http://dx.doi.org/10.5966/sctm.2012-0076. PMid:23197873.

Gosden RG, Boulton MI, Grant K, Webb R. Follicular development from ovarian xenografts in SCID mice. J Reprod Fertil. 1994;101(3):619-23. http://dx.doi.org/10.1530/jrf.0.1010619. PMid:7966017.

Hajian M, Hosseini SM, Ostadhosseini S, Nasr-Esfahani MH. Comparative stepwise pattern of reactive oxygen species production during in vitro development of fertilized and nuclear transferred goat embryos. Int J Fertil Steril. 2017;11(2):93-8. http://dx.doi.org/10.22074/ijfs.2017.5049. PMid:28670426.

Hernandez-Fonseca HJ, Bosch P, Miller DM, Wininger JD, Massey JB, Brackett BG. Time course of follicular development after bovine ovarian tissue transplantation in male non-obese diabetic severe combined immunodeficient mice. Fertil Steril. 2005;83(4, Suppl 1):1180-7. http://dx.doi.org/10.1016/j.fertnstert.2004.07.985. PMid:15831291.

Hoff J. Methods of blood collection in the mouse [Internet]. Labome; 2000 [cited 2018 May 13]. Available from: http://www.labome.com/method/Laboratory-Mice-and-Rats.html 
Ingberg E, Theodorsson A, Theodorsson E, Strom JO. Methods for long-term 17 $\beta$-estradiol administration to mice. Gen Comp Endocrinol. 2012;175(1):188-93. http://dx.doi.org/10.1016/j.ygcen.2011.11.014. PMid:22137913.

Khan MZ, Khan B, Awan MS, Begum F. Livestock depredation by large predators and its implications for conservation and livelihoods in the Karakoram Mountains of Pakistan. Oryx. 2018;52(3):519-25. http://dx.doi.org/10.1017/S0030605316001095.

Kumari AG, Rooh UA, Sadasiva RK. Morphometric and histological characterization of goat fetal ovaries. Dairy and Vet Sci J. 2017;3(1):555605. http://dx.doi.org/10.19080/JDVS.2017.03.555605.

Laschke MW, Menger MD, Vollmar B. Cryopreservation does not affect neovascularization of freely transplanted ovarian follicles. Fertil Steril. 2003;79(6):1458-60. http://dx.doi.org/10.1016/S00150282(03)00359-5. PMid:12798902.

Leal ÉSS, Vieira LA, Sá NAR, Silva GM, Lunardi FO, Ferreira ACA, Campello CC, Alves BG, Cibin FWS, Smitz J, Figueiredo JR, Rodrigues APR. In vitro growth and development of isolated secondary follicles from vitrified caprine ovarian cortex. Reprod Fertil Dev. 2018;30(2):359-70. http://dx.doi.org/10.1071/RD16487. PMid:28768567.

Lee J, Kim SK, Youm HW, Kim HJ, Lee JR, Suh CS, Kim SH. Effects of three different types of antifreeze proteins on mouse ovarian tissue cryopreservation and transplantation. PLoS One. 2015;10(5):e0126252. http://dx.doi.org/10.1371/journal.pone.0126252. PMid:25938445.

Liu L, Wood GA, Morikawa L, Ayearst R, Fleming C, McKerlie C. Restoration of fertility by orthotopic transplantation of frozen adult mouse ovaries. Hum Reprod. 2008;23(1):122-8. http://dx.doi.org/10.1093/humrep/dem348. PMid:17993475.

Magalhães DM, Duarte ABG, Araújo VR, Brito IR, Soares TG, Lima IMT, Lopes CAP, Campello CC, Rodrigues APR, Figueiredo JR. In vitro production of a caprine embryo from a preantral follicle cultured in media supplemented with growth hormone. Theriogenology. 2011;75(1):182-8. http://dx.doi.org/10.1016/j.theriogenology.2010.08.004. PMid:20875671.

Mofarahe ZS, Novin MG, Salehnia M. Folliculogenesis-associated genes expression in human vitrified ovarian tissue after xenotransplantation in y-irradiated mice. Cell J. 2020;22(3):253-400. https://doi.org/10.22074/cellj.2020.6553.

Mohammadi Z, Hayati Roodbari N, Parivar K, Salehnia M. Supplementation of culture media with lysophosphatidic acid improves the follicular development of human ovarian tissue after xenotransplantaion into the back muscle of $y$-irradiated mice. Cell J. 2020;22(3):358-66. http://dx.doi.org/10.22074/cellj.2020.6752. PMid:31863662.

Noorafshan A, Ahmadi M, Mesbah SF, Karbalay-Doust S. Stereological study of the effects of letrozole and estradiol valerate treatment on the ovary of rats. Clin Exp Reprod Med. 2013;40(3):115-21. http://dx.doi.org/10.5653/cerm.2013.40.3.115. PMid:24179868.

Pellicer-Rubio MT, Boissard K, Forgerit Y, Pougnard JL, Bonné JL, Leboeuf B. Evaluation of hormone-free protocols based on the "male effect" for artificial insemination in lactating goats during seasonal anestrus. Theriogenology. 2016;85(5):960-9. http://dx.doi.org/10.1016/j.theriogenology.2015.11.005. PMid:26707385.

Pimentel MM, Santos FA, Teixeira AC, Izzo RG, Lima MA, Macedo MF, Bezerra MB. Biochemical, thermographic, and follicular responses of murine models of hormone-treated bovine ovarian renal capsule xenografts. Pesq Vet Bras. 2017;37(5):425-31. http://dx.doi.org/10.1590/s0100$736 \times 2017000500001$.

Praxedes ÉCG, Lima GL, Bezerra LGP, Santos FA, Bezerra MB, Guerreiro DD, Rodrigues APR, Domingues SFS, Silva AR. Development of fresh and vitrified agouti ovarian tissue after xenografting to ovariectomised severe combined immunodeficiency (SCID) mice. Reprod Fertil Dev. 2018;30(3):45968. http://dx.doi.org/10.1071/RD17051. PMid:28784201.

Roshnath R, Sethu D, Gokul D, Arjun CP. Concerns about Wild Dog (Cuon alpinus) Predation on Livestock in the Fringes of Aralam Wildlife Sanctuary, Kannur, Kerala. Indian For. 2017;143(10):1037-41. http://dx.doi.org/10.1071/RD17051.

Santos FA, Pimentel MML, Teixeira ACG, Cosmo ÍC, Lima MA, Brito PD, Bezerra MB. Follicular right shift: xenografting queen's ovarian tissue into severe combined imunnodeficiency mice and its responses to exogenous gonadotropin. Theriogenology. 2016;86(7):1811-7. http://dx.doi.org/10.1016/j.theriogenology.2016.05.034. PMid:27371971. 
Santos RR, Amorim C, Cecconi S, Fassbender M, Imhof M, Lornage J, Paris M, Schoenfeldt V, MartinezMadrid B. Cryopreservation of ovarian tissue: an emerging technology for female germline preservation of endangered species and breeds. Anim Reprod Sci. 2010;122(3-4):151-63. http://dx.doi.org/10.1016/j.anireprosci.2010.08.010. PMid:20832203.

Santos RR, Knijn HM, Vos PL, Oei CH, Van Loon T, Colenbrander B, Gadella BM, van den Hurk R, Roelen BA. Complete follicular development and recovery of ovarian function of frozen-thawed, autotransplanted caprine ovarian cortex. Fertil Steril. 2009;91(4, Suppl):1455-8. http://dx.doi.org/10.1016/j.fertnstert.2008.07.018. PMid:18722611.

Saraiva MV, Rossetto R, Brito IR, Celestino JJ, Silva CM, Faustino LR, Almeida AP, Bruno JB, Magalhães DM, Matos MH, Campello CC, Figueiredo JR. Dynamic medium produces caprine embryo from preantral follicles grown in vitro. Reprod Sci. 2010;17(12):1135-43. http://dx.doi.org/10.1177/1933719110379269. PMid:20926838.

Senbon S, Ishii K, Fukumi Y, Miyano T. Fertilization and development of bovine oocytes grown in female SCID mice. Zygote. 2005;13(4):309-15. http://dx.doi.org/10.1017/S0967199405003400. PMid:16388699.

Soleimani R, Heytens E, Oktay K. Enhancement of neoangiogenesis and follicle survival by sphingosine-1phosphate in human ovarian tissue xenotransplants. PLoS One. 2011;6(4):e19475. http://dx.doi.org/10.1371/journal.pone.0019475. PMid:21559342.

Tahaei LS, Eimani H, Hajmusa G, Fathi R, Valojerdi MR, Shahverdi A, Eftekhari-Yazdi P. Follicle development of xenotransplanted sheep ovarian tissue into male and female immunodeficient rats. Int J Fertil Steril. 2015;9(3):354-60. http://dx.doi.org/10.22074/ijfs.2015.4551. PMid:26644859.

Van Eyck AS, Bouzin C, Feron O, Romeu L, Van Langendonckt A, Donnez J, Dolmans MM. Both host and graft vessels contribute to revascularization of xenografted human ovarian tissue in a murine model. Fertil Steril. 2010;93(5):1676-85. http://dx.doi.org/10.1016/j.fertnstert.2009.04.048. PMid:19539913.

Wiedemann C, Hribal R, Ringleb J, Bertelsen MF, Rasmusen K, Andersen CY, Kristensen SG, Jewgenow K. Preservation of primordial follicles from lions by slow freezing and xenotransplantation of ovarian cortex into an immunodeficient mouse. Reprod Domest Anim. 2012;47(Suppl 6):300-4. http://dx.doi.org/10.1111/rda.12081. PMid:23279524.

Wolvekamp MCJ, Cleary ML, Cox SL, Shaw JM, Jenkin G, Trounson AO. Follicular development in cryopreserved common wombat ovarian tissue xenografted to nude rats. Anim Reprod Sci. 2001;65(1-2):135-47. http://dx.doi.org/10.1016/S0378-4320(00)00228-1. PMid:11182515.

Yang M, Hall J, Fan Z, Regouski M, Meng Q, Rutigliano HM, Stott R, Rood KA, Panter KE, Polejaeva IA. Oocytes from small and large follicles exhibit similar development competence following goat cloning despite their differences in meiotic and cytoplasmic maturation. Theriogenology. 2016;86(9):2302-11. http://dx.doi.org/10.1016/j.theriogenology.2016.07.026. PMid:27650944.

Youm HW, Lee JR, Lee J, Jee BC, Suh CS, Kim SH. Optimal vitrification protocol for mouse ovarian tissue cryopreservation: effect of cryoprotective agents and in vitro culture on vitrified-warmed ovarian tissue survival. Hum Reprod. 2014;29(4):720-30. http://dx.doi.org/10.1093/humrep/det449. PMid:24365801.

\section{Author contributions}

MMLP: Conceptualization, Data curation, Formal analysis, Investigation, Methodology, Project administration, Writing - original draft, Writing - review \& editing; FAS: Conceptualization, Data curation, Formal analysis, Investigation, Methodology, Project administration, Writing - original draft, Writing - review \& editing; LBM: Conceptualization, Data curation, Formal analysis, Investigation, Methodology, Project administration, Writing - original draft, Writing - review \& editing; PDB: Conceptualization, Data curation, Formal analysis, Investigation, Methodology, Project administration, Writing - original draft, Writing - review \& editing; GLL: Conceptualization, Data curation, Formal analysis, Investigation, Methodology, Project administration, Writing - original draft, Writing - review \& editing; RABJ: Writing - review \& editing; MBB: Methodology, Project administration, Writing - original draft, Writing - review \& editing, Supervision. 